\title{
Disturbance to Surface Lithic Components of Archaeological Sites by Drill Seeding
}

\author{
Neal M. Bryan, ${ }^{1}$ Val Jo Anderson, ${ }^{2}$ and Rachel A. Fugal ${ }^{3}$ \\ Authors are ${ }^{1}$ Doctoral candidate, Department of Agronomy and Horticulture, University of Nebraska-Lincoln, Lincoln, NE 68521, USA; and \\ ${ }^{2}$ Department Chair and ${ }^{3}$ Research Associate, Department of Plant and Wildlife Sciences, Brigham Young University, Provo, UT 84602, USA.
}

\begin{abstract}
Federally funded range improvement treatments in the United States require that land managers consider the treatment's impacts to archaeological sites. Pending archaeological clearance can result in the postponement or exclusion of effective seeding practices, which in turn can result in poor seed establishment, increased weeds, recurrent fire, accelerated soil erosion, and damage to cultural sites. Less intensive requirements would help relieve time restrictions, but less-conspicuous sites might be missed. We quantified the displacement and damage that lithic artifacts would incur if missed in an inventory and subsequently subjected to drill seeding treatments. We subjected chert, quartzite, and obsidian materials to impact by a rangeland drill and a no-till drill on sandy and silty soils. Soil texture was the most important factor in perpendicular lithic movement. In the silty soil, lithics were displaced perpendicular to the direction of the drill nearly twice as far as in the sandy soil $(7.8 \mathrm{~cm} \pm 0.9 \mathrm{SE}$ vs. $4.1 \mathrm{~cm} \pm 0.6 \mathrm{SE}, P<0.01)$. No experimental factor showed a difference in absolute displacement (mean $=15 \mathrm{~cm})$. Damage to lithics was infrequent $(25 \%)$ and minor with no experimental factor showing statistical significance. Approximately $30 \%$ of lithics were buried by treatments. In the sandy soil, the rangeland drill buried lithics $6.5 \mathrm{~mm} \pm 1.6 \mathrm{SE}$ deep, on average, which was twice as deep as the no-till drill in the sandy soil $(3.0 \mathrm{~mm} \pm 0.9 \mathrm{SE})$ and four times as deep as both drills in the silty soil $(1.5 \mathrm{~mm} \pm 0.5 \mathrm{SE} ; P=0.03)$. Minimal effects of drill seeding on lithics suggest that drill seeding could proceed with lessintensive archaeological surveys.
\end{abstract}

\section{Resumen}

Los tratamientos de mejoramiento de pastizales financiados por el gobierno federal de los Estados Unidos requieren que los manejadores de la tierra tomen consideren el impacto de los tratamientos en los sitios arqueológicos. Dependiendo del permiso arqueológico puede dar lugar a demora o a la prohibición de prácticas efectivas de resiembra, que puede traer como consecuencia, pobre establecimiento de la semilla, incremento en malezas y fuegos recurrentes, erosión acelerada del fuego, y daño a los sitios culturales. Unos requisitos menos severos ayudarían a reducir las restricciones del tiempo, pero en sitios menos visibles esto se podría ignorar. Evaluamos el disturbio y el daño que los instrumentos de piedra podrían producir si se ignoraran en un inventario y posteriormente se incluyeran para llevar a cabo en los tratamientos de la siembra. Nos enfocamos en los materiales de cuarzo, obsidiana y xert al impacto de la sembradora de pastizales en suelos arenosos y arcillosos. La textura del suelo fue el factor más importante en el movimiento perpendicular lítico. En el suelo arcilloso, los líticos fueron perpendicularmente desplazados en la dirección de la sembradora casi dos veces en comparación con los suelos arenosos $(7.8 \mathrm{~cm} \pm 0.9 \mathrm{SE}$ vs. $4.1 \mathrm{~cm} \pm 0.6 \mathrm{SE}, P<0.01)$. Ningún factor experimental demostró una diferencia en la separación absoluta (media $=15 \mathrm{~cm}$ ). El daño a los líticos fue infrecuente $(25 \%)$ y menor sin que ningún factor experimental presentara alguna diferencia estadística. Aproximadamente $30 \%$ de los líticos fueron enterrados por los tratamientos. En suelos arenosos, la sembradora de pastizales enterró los líticos a una profundidad promedio de $6.5 \mathrm{~mm} \pm 1.6 \mathrm{SE}$, que fue dos veces más profunda que el tratamiento sin voltear la tierra en los suelos arenosos $(3.0 \mathrm{~mm} \pm 0.9 \mathrm{SE})$ y cuatro veces más profundos en ambos en los suelos arcillosos $(1.5 \mathrm{~mm} \pm 0.5 \mathrm{SE} ; P=0.03)$. Los efectos mínimos de las sembradoras en los líticos sugieren que la resiembra utilizando sembradoras podría llevarse a cabo en aquellos sitios arqueológicos con análisis menos intensivos.

Key Words: archaeological clearance, drill seeding impacts, lithic scatters, provenance, revegetation

\section{INTRODUCTION}

Invasion of exotic annual species after disturbance of rangelands leads to further degradation of ecosystems throughout the Intermountain West region of the United States, particularly in the salt desert, sagebrush, and pinyon-juniper zones (Knapp

\footnotetext{
Research was funded by Brigham Young University.

Research was a portion of Bryan's MS degree work, Integrative Biology Department, Brigham Young University, Provo, UT 84602, USA.

Correspondence: Rachel A. Fugal, Dept of Plant and Wildlife Sciences, Brigham Young University, 275 WIDB Provo, UT 84602, USA. Email: chelrann@gmail.com

Manuscript received 28 May 2009; manuscript accepted 21 November 2010.
}

1996; Goodrich and Rooks 1999; Ott et al. 2001). Increased resource competition and increased fire occurrence are the mechanisms of a positive feedback loop that eventually results in a fire-adapted, annual disclimax community. Prevention or early disruption of this destructive cycle is much less costly and more effective than restoring rangelands after the establishment of invasive species (Jenkins 2002). Furthermore, establishing an ecosystem resistant to invasion can yield better results than focusing efforts toward eradicating established invaders (Hobbs and Humphries 1995). Effective and timely revegetation of disturbed sites in the Intermountain West is an essential component of preempting annual weed invasion through establishing a resistant plant community (Goodrich and Rooks 
1999; Ott et al. 2001). Seeding is more successful if the seedbed is prepared to create microsites and seeds are placed in intimate contact with soil (Winkel et al. 1991). When feasible in scale and terrain, a rangeland seed drill is preferred (Vallentine 1989). Most importantly, perennials must be sown before annuals dominate a site (Allen 1995; Tausch et al. 1995) and in such a season as to take advantage of soil moisture.

One consideration that can delay seeding following disturbances is conducting archaeological compliance. It is generally understood that cultural resources are nonrenewable and should be protected (Nickens 1991). Prior to conducting a federal or state funded project in the United States, which has the potential for ground disturbance, cultural resources need to be considered (National Historic Preservation Act 1966, section 106, 36 CFR 800 and USC §9-8-404). The Federal Land Policy and Management Act of 1976 specifically includes archaeological values in its multiple use management mandate (section 1701). These laws do not specify required methods of surveying for cultural resources. According to the National Historic Preservation Act 1966, the State Historic Preservation Office (SHPO) must be informed during the planning process and will offer consultation, but the decisions concerning the methods of conducting surveys are left to the discretion of the individual government agencies. Upon completion of each survey, a written report documenting the process and any sites that were discovered must be given to SHPO. Subsequently, there is a mandatory $30-\mathrm{d}$ waiting period for SHPO to respond before the project can be initiated. The amount of time this process requires varies depending on the size of the project, the terrain, the number of archaeological sites discovered, the funding, and the personnel available. When time and funding are limiting factors or in areas where it is known that cultural material will be sparse, it may be appropriate and expeditious for agencies to conduct less intense surveys.

With the limited knowledge we currently have on the revegetation processes and their effects on cultural material, we must assume that they may have the potential to disturb and/or damage cultural resources; however, few studies have been performed to provide empirical evidence of the degree of disturbance. Surprisingly little research has been published on the actual disturbance resulting from mechanical treatment on rangelands, and the few relevant publications are generally concerned with chaining in woodland communities (DeBloois et al. 1974; Gallagher 1978). Regarding site destruction due to agricultural practices, many studies make observations at a large scale (Ford and Rolingson 1972; Medford 1972), some are ad hoc investigations (Redman and Watson 1970; Roper 1976; Trubowitz 1978; Horobik and Parkisons 2008), and nearly all are regarding multiple passes of highly invasive mechanical treatments such as disking or plowing (Redman and Watson 1970; Ford and Rolingson 1972; Medford 1972; Roper 1976; Trubowitz 1978; Jermann 1981; Lewarch and O'Brien 1981; Yorston et al. 1990; Haglund et al. 2001; Horobik and Parkisons 2008). Research investigating the effects of a single pass of a rangeland drill typical of the revegetation process is needed to make informed decisions balancing archaeological values with rangeland health. Our study measured the actual impact of two mechanical seed drills on lithic components typically found at archaeological sites at the level of the artifact on the site and at the level of attributes of the artifact (Knoerl and Versaggi 1984). The null hypothesis was that artificial lithic scatters would be neither significantly displaced nor sustain physical damage by seed drills.

\section{METHODS}

Because seed drills perform differently on different soils, we conducted the evaluation on two sites with different soil textures, both of which were in archaeologically cleared areas. The Sandy Loam site is located at lat $40^{\circ} 11^{\prime} 05^{\prime \prime} \mathrm{N}$, long $112^{\circ} 48^{\prime} 27^{\prime \prime} \mathrm{W}$ and is classified as a Tooele fine sandy loam (US Department of Agriculture, Natural Resources Conservation Service [USDA-NRCS] 2000). The Silty Loam site is located at lat $40^{\circ} 12^{\prime} 27^{\prime \prime} \mathrm{N}$, long $112^{\circ} 48^{\prime} 42^{\prime \prime} \mathrm{W}$ and is classified as a Skumpah silty loam (USDA-NRCS 2000).

We acquired cobbles of three minerals often associated with archaeological sites: chert, quartzite, and obsidian. Obsidian lithics were divided into two sets. One set was simple flakes, and the other set was mechanically shaped into bifaces. Cobbles were reduced to pieces ranging from $2 \mathrm{~cm}$ to $13 \mathrm{~cm}$ long and weighing from $2 \mathrm{~g}$ to $133 \mathrm{~g}$. We marked selected pieces with a unique code using a contrasting color of fingernail polish. We took a digital photograph of both surfaces of every lithic piece before treatment. Because of a shortage of suitable lithic pieces, lithic size was not an experimental factor, but all lithic sizes were exposed to all treatments.

We used a rangeland drill with disks $30.5 \mathrm{~cm}$ (12 in) apart with drag chains and a no-till drill with disks $20.3 \mathrm{~cm}$ (8 in) apart as our mechanical treatments. A disturbance treatment was defined as a single pass of the respective drill over a plot. We assessed percent ground disturbance for each drill on both sites using line intercept transects. We measured intercept distances of mechanical contact in the furrow, soil cast from the furrow, and undisturbed areas to the nearest centimeter. To test the hypothesis of no significant impact, we first quantified displacement at the artifact level due to the action of two seed drills, on two soils with different texture, and then described physical damage at the attribute level that resulted from direct impact of a drill disk. Trials tested movement and physical damage to lithics as the drill passed over the plot under normal field conditions.

We designed the trials to ensure mechanical impact of the drill disks on all pieces. A drill was pulled in a straight line to help predict where the drill disks would pass. Excluding furrows directly behind tractor tires, we randomly chose three furrows and lifted those disks. We strung a taut line down each selected furrow, extending it beneath and beyond the drill. We used centimeter-demarcated frames measuring $0.25 \mathrm{~m}$ by $2 \mathrm{~m}$ for locating lithics. We centered each frame over the taut line in front of the drill, with the long dimension parallel to the taut line, and staked each frame at opposite corners with $30.5 \mathrm{~cm}$ (12 in) metal spikes. Beneath the taut line within each frame, we arranged five lithic pieces of the same mineral type, spacing them along the length of the frame and pressing every lithic into intimate contact with the mineral soil surface. If a lithic had an obvious longitudinal axis, we oriented it in an independently random direction. We recorded the beginning $x, y$ position within the frame for each lithic. We then removed the measuring frames from the metal spikes and pulled the lowered 

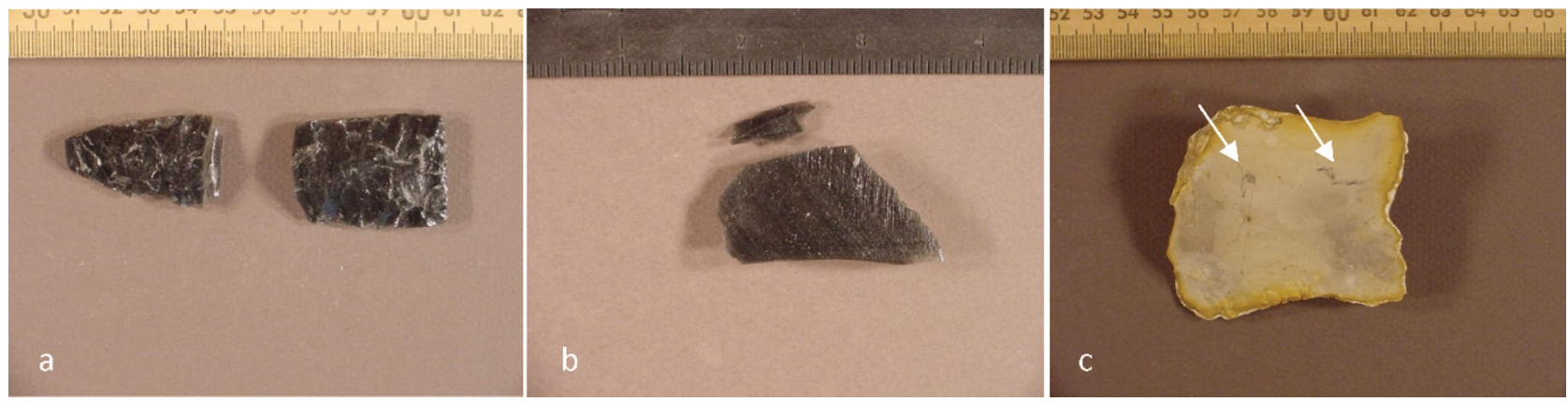

Figure 1. Obsidian biface exhibiting simple fracture (damage score of 3, image a) due to impact by seed drill. Obsidian flake exhibiting edge break (damage score of 2, image b) due to impact by seed drill. Chert scraper exhibiting metal-on-stone marking indicated by arrows (damage score of 1 , image c) due to impact by seed drill.

drill over the lithic pieces. Drag chains on the rangeland drill were deployed. Tractors were engaged to impart drills at a typical rangeland seeding speed of approximately $6 \mathrm{~km} \cdot \mathrm{h}^{-1}$ $\left(3.7 \mathrm{mi} \cdot \mathrm{h}^{-1}\right)$.

After each pass of a drill, we replaced the measuring frame over the metal spikes and recorded a new $x, y$ coordinate within the frame for each lithic piece. When necessary, we probed with a piece of wire to find buried lithics and measured burial depth from the new soil surface to the top of the mineral piece. The pieces were collected and photographed after each treatment.

We visually compared the pre- and post-treatment photographs and rated damage on a 0 to 4 scale, increasing with damage severity. A score of 4 denoted a shattering fracture, defined as a break into more than two pieces. A simple fracture (a break into two subequal pieces) received a score of 3 , an edge nick or flake was scored as 2 , and an abrasion scored a 1 (Fig. 1). No apparent physical damage was scored a 0.

Treatments were replicated three times. We tested soil, equipment, and mineral type in a three-factor factorial, randomized complete block design. The responses of the five lithics in each frame were averaged for analysis with General Linear Model (GLM) in SAS (SAS Institute 1999). Horizontal displacement was analyzed as three categories: 1) displacement parallel to drill movement (change in $x$ ), 2) displacement perpendicular to drill movement (change in $y$ ), and 3) absolute displacement (hypotenuse of triangle with sides $x$ and $y$ ). GLM was also used to detect differences in percent soil disturbances due to equipment and soil factors.

\section{RESULTS}

\section{Soil Disturbance}

On a percentage basis, the type of drill was significant in ground disturbance $(P<0.05)$. The rangeland drill cut a wider furrow and cast soils 5\% further than the no-till drill, but it mechanically impacted slightly less ground $(71 \%$ disturbance vs. $75 \%$ ) because of wider disk spacing. Percentages of cast soil and undisturbed soil were inversely proportional and determined by the type of soil. Silty soil was cast further than the sandy soil $(P<0.05)$; thus silty soil had more cast-disturbed $(41 \%$ vs. $33 \%$ in the sandy soil) and less undisturbed area ( $23 \%$ undisturbed vs. $31 \%$ in the sandy soil).

\section{Lithic Damage}

Lithic damage was low $($ mean $=0.4$; mode $=0)$ and was not significantly affected by soil, drill, or lithic type. A single lithic suffered a multiple fracture and seven lithics sustained a simple fracture. Combined, all fractured lithics represented only $3.4 \%$ of our sample. Fifty lithics either had an edge chipped or were visibly marked by a disk. All lithics that were damaged to any degree comprised less than $25 \%$ of all lithics exposed to treatment.

\section{Lithic Burial}

The soil and equipment interaction was significant $(P=0.03)$ for burial depth (Fig. 2). In the sandy soil, the rangeland drill buried lithics $6.5 \mathrm{~mm} \pm 1.6 \mathrm{SE}$ deep on average, which was twice as deep as the no-till drill $(3.0 \mathrm{~mm} \pm 0.9 \mathrm{SE})$. In the silty soil, drill effect was virtually identical, with a mean depth of $1.5 \mathrm{~mm} \pm 0.5 \mathrm{SE}$. Considering only buried lithics, the mean burial depth was $1.0 \mathrm{~cm}$. Neither the type of drill nor the type of soil affected the frequency of burial (approximately $30 \%$ ).

\section{Lithic Displacement}

There was no difference between parallel and absolute displacement. In the silty soil, lithics were displaced perpendicular to the direction of the drill nearly twice as far $(7.8 \mathrm{~cm} \pm 0.9 \mathrm{SE})$ as in the sandy soil $(4.1 \mathrm{~cm} \pm 0.6 \mathrm{SE}$; $P<0.01$; Fig. 2). Drill type and lithic mineral type had no effect on displacement. Mean absolute displacement for all lithics was $15 \mathrm{~cm}$. Considering absolute displacement of individual lithics for both drills in both soils (Fig. 3), the maximum measured displacement for a single lithic was $3.1 \mathrm{~m}$, but median displacement was only $9 \mathrm{~cm}$.

\section{DISCUSSION}

\section{Soil Disturbance}

Less soil was disturbed on the sandy site because less momentum energy was transferred through the soil from the approaching disk. Lithics on sandy soil were therefore more likely to slide down into the furrow, as described by Knoerl and Versaggi (1984), and to show less horizontal movement. This also means that with other factors being equal, higher velocity drilling would have higher momentum energy and, thus, could cast soil and associated lithics further. Less soil would remain undisturbed, although the zone of actual mechanical impact 

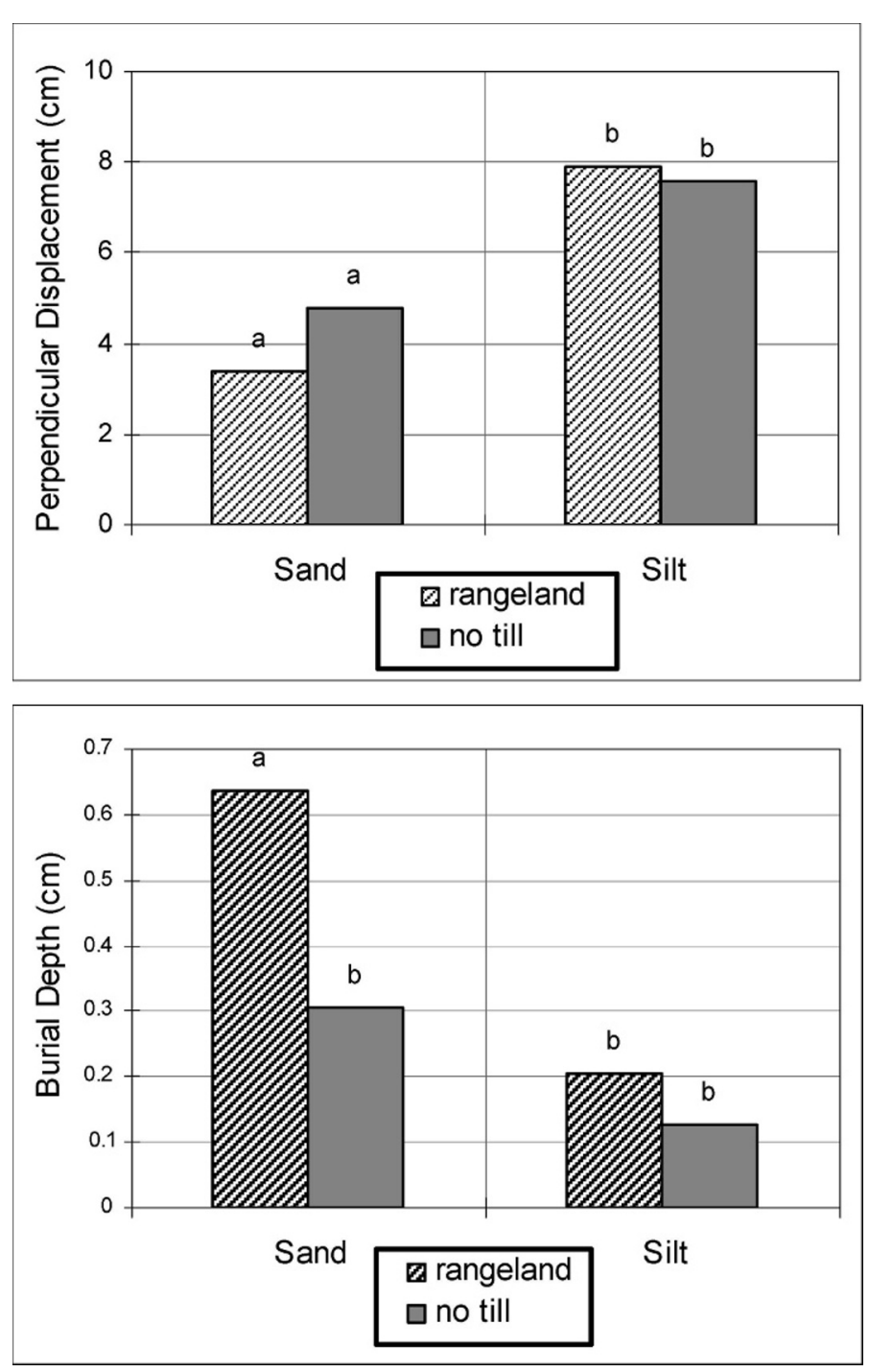

Figure 2. Lithic displacement perpendicular to drill direction and burial depth of lithic pieces following treatment with two seed drills on two soil types in Tooele County, Utah: Lithic displacement soil effect $(P=0.004)$, burial depth soil, and drill interaction $(P=0.03)$. Means with same letter are not significant at $\alpha=0.05$.

would remain the same. The soil texture factor has not been investigated specifically in other studies concerning artifact displacement by mechanical treatment and possibly contributes to the range of reported differences in the extent of lithic movement.

\section{Lithic Damage}

Physical damage sustained by lithics in this study was minimal, especially considering natural pedoturbation processes that may cause damage as well (Butzer 1982). Knoerl (1976) found an identical 1:11 ratio of edge-damaged to undamaged lithics in both plow-disturbed and nondisturbed sites. Our results show higher rates of edge damage than this, but damage incidence is inflated in this study, because we placed lithics directly in the mechanical impact zone.

In application, not all lithics will be subject to mechanical contact, but will be randomly affected with respect to a pass of a drill. Only lithics in mechanically contacted areas are at risk for damage or displacement, although we have shown that these lithics are rather likely to be cast aside with soil or to slide down the disk blade into the furrow, depending on the soil texture. Lithics in areas adjacent to furrows could be covered with soil cast from the furrow. These lithics are less likely to move and are not likely to be damaged, but will be buried more often and possibly deeper than in the other zones. Finally, lithics between furrows will not be displaced or damaged at all.

\section{Lithic Burial}

Differences in burial were directly influenced by the soil and equipment interaction. As the drill passed, the edge of the furrow tended to collapse to the bottom (more so in sandy soils, and especially with the rangeland drill's drag chains deployed) resulting in deeper burial. In the sandy soil, the rangeland drill cut deeper furrows than the no-till drill and resulted in increased burial depth. The rangeland drill disks have depth bands that can be ineffective on soils with loose texture (Vallentine 1989), while the no-till drill furrow depth is hydraulically controlled and more suited to loose soils. On the silty soil, the rangeland drill's depth bands better regulated furrow depth, and both drills had similar burial effect. This study did not address artifacts below the soil surface, which are often uncovered by mechanical treatment (Ford and Rolingson 1972; Jermann 1981).

\section{Lithic Displacement}

The $15 \mathrm{~cm}$ mean displacement in our study is, as expected, less than the displacement found in similar studies conducted with more invasive and repeated mechanical treatments. Trubowitz (1978) found that tiles moved an average of $1.6 \mathrm{~m}$ after a year and a half and three cultivation episodes. Lewarch and O'Brien (1981), in a study using one to three passes of a disk plow, found a $40-\mathrm{cm}$ average horizontal displacement and less than 3$\mathrm{m}$ vertical displacement. In a study including 164 sherds subjected to $6 \mathrm{yr}$ of ploughing in the southern English chalklands, Yorston et al. (1990) found an average 50-cm displacement.

Precision of typical provenance methods, the amount of movement due to natural pedoturbation, surface:subsurface correlation, and the capability of data analysis to compensate for movement are all considerations in determining how much movement due to drill seeding is acceptable. The average displacement of $15 \mathrm{~cm}$ and maximum of $3 \mathrm{~m}$ observed are not likely to affect the results of most studies involving provenance data. The resolution of data collection or the scale of analysis in most cases would subsume this degree of movement (Redman and Watson 1970; Roper 1976; Jermann 1981; Lewarch and O’Brien 1981; Nance and Ball 1981; O’Connell 1993; Tipps 1993).

On an extremely short time scale, displacement due to drill seeding may appear to be significant. However, many lithic artifacts have been on archaeological sites for thousands of years, exposed to the forces of wind, water, soil, ice, salt, gravity, seismic activity, animals, plants, and human pedoturbation (Wood and Johnson 1978; Surovell et al. 2005). Given these factors and other postdepositional effects, surface or 


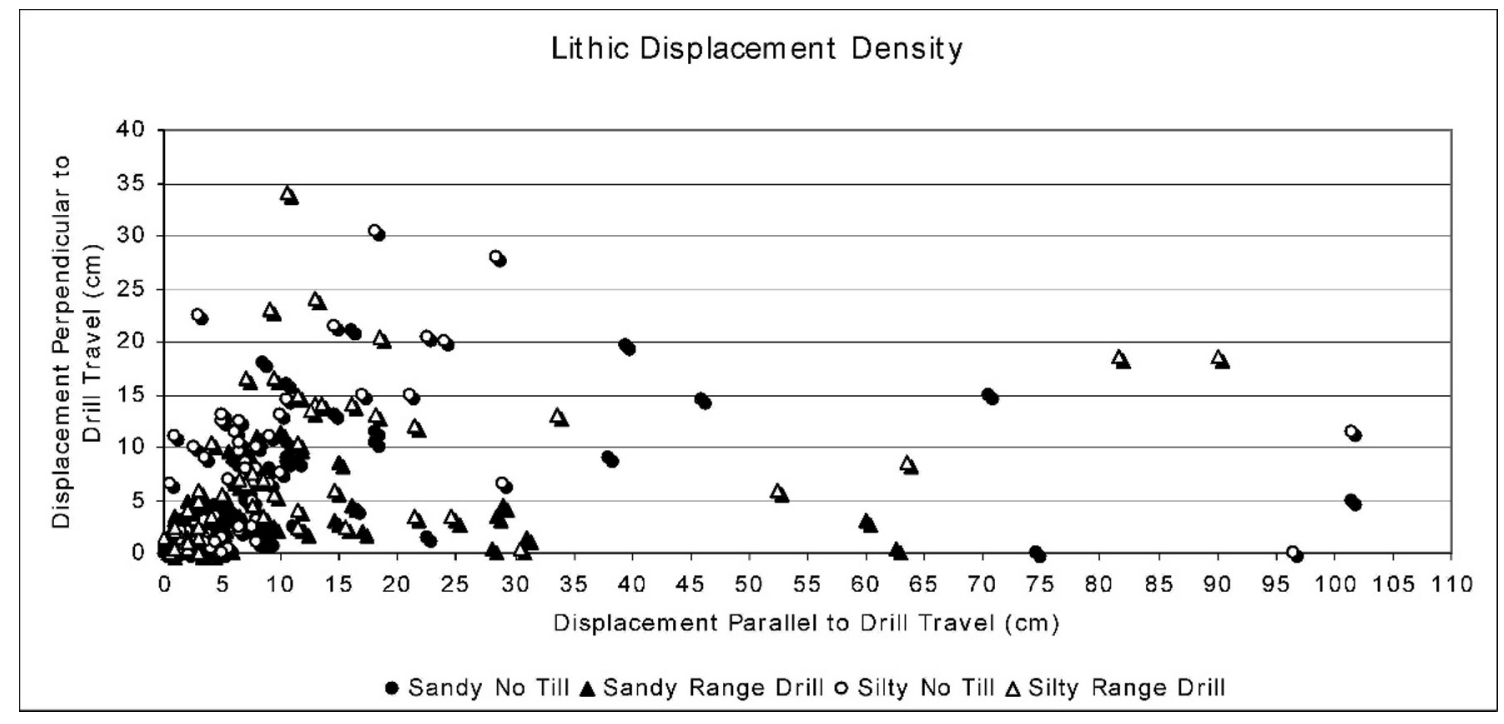

Figure 3. Absolute displacement (parallel $\times$ perpendicular) of individual lithics with two seed drills on two soil types in Tooele County, Utah. Two outliers, one displaced $9 \mathrm{~cm}$ perpendicular and $158 \mathrm{~cm}$ parallel and the other $31 \mathrm{~cm}$ perpendicular and $311 \mathrm{~cm}$ parallel to the drill, are not depicted.

subsurface artifacts cannot be assumed to have originated where they are found (Butzer 1982; Hivernel and Hodder 1984). In a study conducted in Canyonlands National Park, movement due to natural processes was found to be $10-25 \mathrm{~cm}$ on average, with some approaching $50 \mathrm{~cm}$ and at a slick rock site an average of $225 \mathrm{~cm}$ over the course of $6 \mathrm{yr}$ (Hartley 1991). Comparing displacement over a longer time scale may show that drill seeding, by establishing stable plant communities, dampens pedoturbation due to natural processes.

The effect of mechanical treatment on the correlation between surface and subsurface artifact location is controversial. Binford (1970), Redman and Watson (1970), and Trubowitz (1978) all contend that subsurface assemblages are always highly correlated with those on the surface, but more recent work suggests that surface collections are not necessarily representative of subsurface collections (Yorston et al. 1990; Haglund et al. 2001; Horobik and Parkisons 2008). The literature is inconclusive, but suggests that if natural processes and provenance precision are considered, drill seeding will not significantly affect surface/subsurface correlation.

Unlike movement due to natural processes, movement due to mechanical treatment is easier to identify and analyze (Butzer 1982). One possibility demonstrated by Lewarch and O'Brien (1981) consisted of diminishing tillage effects through transformation of artifact counts with a proportional weighting algorithm in the direction of equipment movement. Others suggest using multiple analytical techniques to compensate for postdepositional disturbance (Johnson 1984; Kintigh 1990; Gregg et al. 1991; Surovell et al. 2005). To test the robustness of this technique, Gregg et al. (1991) analyzed a real huntergatherer site and then computer-simulated three different disturbance regimes and reanalyzed the data for comparison. By combining pure locational and composition assemblage approaches, the integrity of the site structure, assemblage composition, and pattern of distribution were discernible at all levels of disturbance despite the loss of resolution.

\section{MANAGEMENT IMPLICATIONS}

Drill seeding may carry less risk to cultural sites than no treatment at all. Archaeological sites in the Intermountain West region of the United States, particularly in the salt desert, sagebrush, and pinyon-juniper zones mitigated by avoidance, are characterized by bare soil or annual weeds, while adjacent drill-seeded areas have established perennial grass cover (Ott et al. 2003). Erosion risk on these sites increases dramatically with low vegetation cover (Marshall 1973). Soil loss not only decreases the potential of a range site to support vegetation (Tueller 1973), but also can cause archaeological site deflation and destruction of stratigraphy (Wood and Johnson 1978). Vandalism is also a concern, as these sites are readily identified as avoidance-mitigated and are visible for miles (Fig. 4). Delaying sowing after fire to avoid displacement or damage of lithics by drill seeding equipment does not justify the risk of

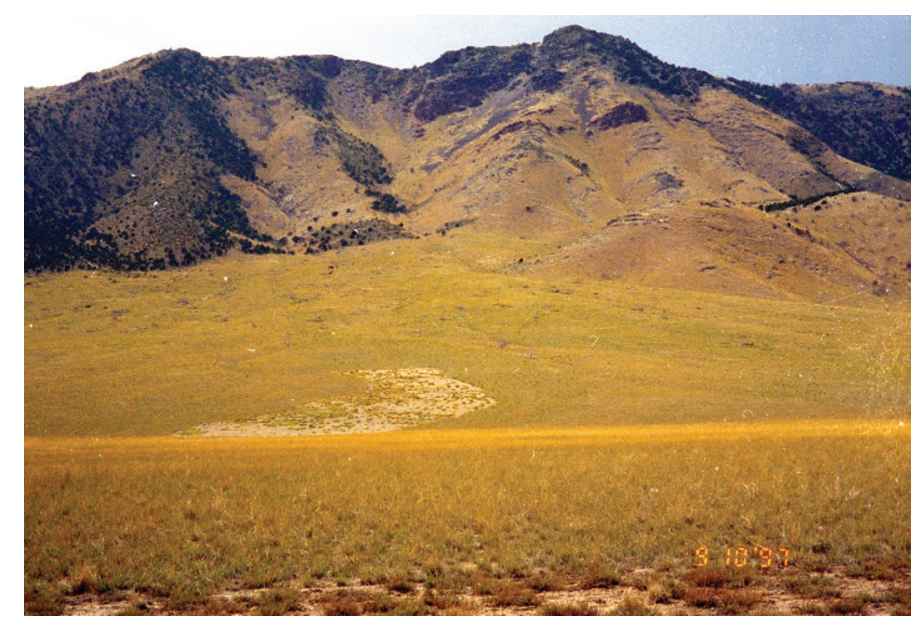

Figure 4. Avoidance-mitigated cultural site (light area at center) in central Utah. Boundaries of site are visible for miles. Photo from BLM 1997. Reproduced with permission. 
erosion, invasion by annual weeds, or ensuing cyclic fire degradation. Seeding success improves when seeds are covered by some means and drill seeding can accomplish this goal satisfactorily while posing negligible risk to archaeological sites characterized by surface lithic scatters. Displacement or damage due to rangeland drill seeding is likely no more significant than that caused by natural pedoturbation. Given the ecological and archaeological damage that can occur with avoidance mitigation, it may be valuable to test impact of other revegetation techniques on lithic scatters. For instance, anchor chaining is a muchmaligned practice that may actually disturb surface sites less than drill seeding. In contrast to drill seeding, in which disks are in continuous contact with the ground, chain links are alternately lifted and dropped as the chain rolls. Chaining in conjunction with aerial seeding can be used where drilling is not feasible, such as wooded areas or steep terrain (Vallentine 1989). Given our findings, more mechanical rangeland manipulation techniques should be tested for their effect on lithic pieces.

\section{LITERATURE CITED}

Allen, E. B. 1995. Restoration ecology: limits and possibilities in arid and semiarid lands. In: B. A. Roundy, E. D. McArthur, J. S. Haley, and D. K. Mann [Comps.]. Proceeding: wildland shrub and arid land restoration symposium. Ogden, UT, USA: US Department of Agriculture, Forest Service, INT-GTR-315. p. 7-15.

Binford, L. R., S. R. Binford, R. Whallon, and M. A. Hardin. 1970. Archaeology at Hatchery West, Carlyle, Illinois. Memoirs of the Society for American Archaeology 24.

BLM. 1997. Guidelines for protecting archeological sites in proposed treechaining areas. BLM Technical Note 161. Denver, C0, USA: US Department of Interior BLM, Denver Service Center.

Butzer, K. W. 1982. Archaeology as human ecology: method and theory for a contextual approach. New York, NY, USA: Cambridge University Press. $364 \mathrm{p}$.

DeBlools, E., D. Green, and H. Wylie. 1974. A test of the impact of pinyon-juniper chaining on archaeological sites. Ogden, UT, USA: US Department of Agriculture, Forest Service, Archaeological Report, Intermountain Research Station.

Ford, J. L., AND M. RolingSon. 1972. Site destruction due to agricultural practices in southeast Arkansas. Arkansas Archeological Survey Research Series 3:1-40.

GallagheR, J. G. 1978. Scarification and cultural resources: an experiment to evaluate serotinous lodgepole pine forest techniques. Plains Anthropologist 23:289-299.

Goodrich, S., AND D. Rooks. 1999. Control of weeds at a pinyon-juniper site by seeding grasses. In: S. B. Monsen and R. Stevens [EDS.]. Proceedings: ecology and management of pinyon-juniper communities within the interior West. Ogden, UT, USA: US Department of Agriculture, Forest Service, RMRS-P-9. p. 403-407.

GregG, S. A., K. W. Kintigh, and R. Whallon. 1991. Linking ethnoarchaeological interpretation and archaeological data: the sensitivity of spatial analytical methods to postdepositional disturbance. In: E. M. Kroll and T. D. Price [EDs.]. The interpretation of archaeological spatial patterning. New York, NY, USA: Plenum Press. p. 149-196.

Haglund, W. D., M. Connor, and D. D. Scott. 2001. The effect of cultivation on buried human remains. In: W. D. Haglund and M. H. Sorg [EDS.]. Advances in forensic taphonomy: method, theory, and archaeological perspectives. Boca Raton, FL, USA: CRC Press. p. 133-150.

HaRTLEY, R. J. 1991. Experiments on artifact displacement in Canyonlands National Park. Utah Archaeology 4:55-68.

Hivernel, F., and I. Hodder. 1984. Analysis of artifact distribution at Ngenyn (Kenya): depositional and postdepositional effects. In: H. J. Hietala [ED.].
Intrasite spatial analysis in archaeology. Cambridge, United Kingdom: Cambridge University Press. p. 97-115.

HobBS, R. J., AND S. E. HumpHRIES. 1995. An integrated approach to the ecology and management of plant invasions. Conservation Biology 9:761-770.

HorobiK, H., AND W. Parkisons. 2008. Exploring the reliability of archaeological site survey through the GIS based analysis of surface artifact distribution at Körösladány 14. The Journal of Young Investigators: An Undergraduate, PeerReviewed Science Journal 19:1-13. Available at: http://www.jyi.org/research/ re.php?id=1086. Accessed 15 October 2008.

Jenkins, P. T. 2002. Pay for protection from invasive species. Issues in Science and Technology 19:67-73.

Jermann, J. V. 1981. Surface collection and analysis of spatial pattern: an archeological example from the lower Columbia River valley. In: M. J. O'Brien and D. E. Lewarch [EDS.]. Plowzone archeology: contributions to theory and technique. Publications in Anthropology No. 27. Nashville, TN, USA: Vanderbilt University. p. 71-118.

JoHNSON, I. 1984. Cell frequency recording and analysis of artifact distributions. In: H. J. Hietala [ED.]. Intrasite spatial analysis in archaeology. Cambridge, United Kingdom: Cambridge University Press. p. 75-96.

KINTIGH, K. W. 1990. Intrasite spatial analysis: a commentary on major methods. In: A. Voorrips [ED.]. Mathematics and information science in archaeology: a flexible framework. Studies in modern archaeology. Volume 3. Bonn Verlag, Germany: Holos. p. 165-200.

KnapP, P. A. 1996. Cheatgrass (Bromus tectorum L.) dominance in the Great Basin Desert: history, persistence, and influences to human activities. Global Environmental Change 6:37-52.

KNoERL, J. J. 1976. Methodological approaches to site examination at Loder cornfield. In: M. L. Weide [ED.]. I-88 Archaeological Project 1975 Summer Season. Binghamton, NY, USA: SUNY-Binghamton. Manuscript on file in the Public Archaeology Facility at SUNY-Binghamton, Binghamton, NY, USA.

Knoerl, J. J., and N. Versaggi. 1984. Plow zone sites: research strategies and management policy. American Archeology 4:76-80.

Lewarch, D. E., and M. J. O'Brien. 1981. Effect of short term tillage on aggregate provenience surface pattern. In: M. J. O'Brien and D. E. Lewarch [EDS.]. Plowzone archeology: contributions to theory and technique. Publications in Anthropology No. 27. Nashville, TN, USA: Vanderbilt University. p. 7-49

MarshalL, J. K. 1973. Drought, land use and soil erosion. In: J. V. Lovett [ed.]. The environmental, economic and social significance of drought. Sydney, Australia: Angus and Robertson Publishers. p. 55-77.

Medford, L. D. 1972. Site destruction due to agricultural practices in southeast Arkansas. Arkansas Archeological Survey Research Series 3:41-82.

Nance, J. D., And B. F. Ball. 1981. The influence of sampling unit size on statistical estimates in archeological site sampling. In: M. J. O'Brien and D. E. Lewarch [EDS.]. Plowzone archeology: contributions to theory and technique. Publications in Anthropology No. 27. Nashville, TN, USA: Vanderbilt University. p. 51-69.

Nickens, P. R. 1991. The destruction of archaeological sites and data. In: G. Smith and J. Ehrenhard [EDS.]. Protecting the past. Boca Raton, FL, USA: CRC Press. p. 73-81.

O'ConnelL, J. F. 1993. What can Great Basin archaeologists learn from the study of site structure? An ethnoarchaeological perspective. Utah Archaeology 6:7-26.

Ott, J. E., E. D. McArthur, and B. A. Roundy. 2003. Vegetation of chained and nonchained seedings after wildfire in Utah. Journal of Range Management 56:81-91.

Ott, J. E., E. D. McArthur, and S. C. Sanderson. 2001. Plant community dynamics of burned and unburned sagebrush and pinyon-juniper vegetation in westcentral Utah. In: E. D. McArthur and D. J. Fairbanks [EDS.]. Proceedings: shrubland ecosystem genetics and biodiversity. Ogden, UT, USA: US Department of Agriculture, Forest Service, RMRS-P-21. p. 177-191.

Redman, C. L., and P. J. Watson. 1970. Systematic, intensive surface collection. American Antiquity 35:279-291.

Roper, D. C. 1976. Lateral displacement of artifacts due to plowing. American Antiquity 41:372-375.

SAS Institute. 1999. Statistical analysis system. Version 8 [computer program]. Raleigh, NC, USA: SAS Institute Inc. 
Surovell, T. A., N. M. Waguespack, J. H. Mayer, M. Kornfeld, and G. C. Frison. 2005. Shallow site archaeology: artifact dispersal, stratigraphy, and radiocarbon dating at the Barger Gulch Locality B Folsom site, Middle Park, Colorado. Geroarchaeology: An International Journal 20:627-649.

Tausch, R. J., J. C. Chambers, R. R. Blank, and R. S. Novak. 1995. Differential establishment of perennial grass and cheatgrass following fire on an ungrazed sagebrush-juniper site. In: B. A. Roundy, E. D. McArthur, J. S. Haley, and D. K. Mann [comps.]. Proceedings: wildland shrub and arid land restoration symposium. Ogden, UT, USA: US Department of Agriculture, Forest Service, INT-GTR-315. p. 252-257.

TIPPS, B. L. 1993. Investigating the spatial structure of lithic scatter sites from an ethnoarchaeological perspective: examples from Utah and Nevada. Utah Archaeology 6:57-71.

Trubowitz, N. L. 1978. The persistence of settlement pattern in a cultivated field. In: W. Engelbrecht and D. Grayson [EDS.]. Essays in Northeastern Anthropology in memory of Marian E. White. Rindge, NH, USA: Department of Anthropology, Franklin Pierce College, Occasional Publications in Northeastern Anthropology 5. p. 41-66.
TueleER, P. T. 1973. Secondary succession, disclimax, and range condition standards in desert shrub vegetation. In: D. N. Hyder [ED.]. Arid shrublands: proceedings of the 3rd workshop of US/Australia rangelands panel. 26 March-5 April 1973; Tucson, AZ, USA. Denver, C0, USA: Society for Range Management. p. 57-64.

[USDA-NRCS] US Department of Agriculture, Natural Resources Conservation SERvicE. 2000. Soil survey of Tooele Area, Utah. Washington, DC, USA: US Department of Agriculture Soil Conservation Service.

Vallentine, J. F. 1989. Range development and improvements. 3rd ed. San Diego, CA, USA: Academic Press. 524 p.

Winkel, V. K., B. A. Roundy, AND J. R. Cox. 1991. Influence of seedbed microsite characteristics on grass seedling emergence. Journal of Range Management 44:210-214.

Wood, W. R., AND D. L. Johnson. 1978. A survey of disturbance processes in archaeological site formation. In: M. B. Schiffer [ED.]. Advances in archaeological method and theory. Volume 1. San Francisco, CA, USA: Academic Press. p. 315-381.

Yorston, R. M., V. L. Gaffney, and P. J. Reynolds. 1990. Simulation of artifact movement due to cultivation. Journal of Archaeological Science 17:67-83. 